\title{
Performance of SSES in Production Functional Area-An Overview
}

\author{
Pulidindi Venugopal, Ch. Vinoda Rao, S. Aswini Priya
}

\begin{abstract}
Nature of production also affects the health or otherwise of industrial enterprises. Depending upon the nature of market, it can be divided into continuous, seasonal or intermittent. This study explores performance of Small Scale Enterprises in production functional area in India. It is found that duration of dullness of business varied from one industrial category to another and even in the same category between healthy and sick SSEs in Andhra Pradesh. 80 per cent of healthy and 26 per cent of sick SSEs have had dullness ranging from 0-6 months, 16 per cent of healthy and 23 per cent of sick experienced dullness ranging from 6-12 months, 26 per cent of sick faced dullness for a duration of 12-24 months and 25 per cent of sick experienced dullness for a period exceeding 24 months. It is evident that dullness for short spells resulted only in fluctuations in profits, but not resulted in sickness, but dullness for a period exceeding 12-24 months as in Basic Metals and Paper \& Paper Products and for a period exceeding 24 months as in Food Products \& Processing and Textiles, spelt real disaster pushing them into sickness.
\end{abstract}

Keywords: Andhra Pradesh, Basic metals, industrial enterprises, Paper products.

\section{INTRODUCTION}

Slow economic progress achieved by India can be attributed among other things, to lack of determination and capacity among the people to assemble and organize factors of production. Hence, the crucial issue in planning is the development of entrepreneurial abilities and productive employment of such resources. SSIs provide a seed bed for the development of entrepreneurial talents and a testing place for new ventures. Keeping in view the importance of the SSI sector in the Indian economy, the Government of India made considerable efforts to promote their growth during the successive Five Year Plan periods. The strategy for their development comprises of formulation and pursuit of deliberate policies for their protection and development, stepping up of plan allocations, creation of a plethora of supporting institutions, implementation of various programmes, provision of industrial finance on concessional terms and granting of financial and tax incentives. These measures resulted in rapid growth of SSEs in the country

Revised Manuscript Received on September 16, 2019.

* Correspondence Author

Dr. Pulidindi Venugopal, Department of Technology Management, Vellore Institute of Technology, Vellore, India. Email: pulidindi.venu@vit.ac.in

Dr. Ch. Vinoda Rao*, Department of Business Administration, K.G.R.L College of PG courses, Bhimavaram, India. Email: vinod.jaavi@gmail.com

S. Aswini Priya, VIT Business School, Vellore Institute of Technology, Vellore, India. Email: priyapri.254@gmail.com

(C) The Authors. Published by Blue Eyes Intelligence Engineering and Sciences Publication (BEIESP). This is an open access article under the CC BY-NC-ND license (http://creativecommons.org/licenses/by-nc-nd/4.0/)
A production play a vital role depends on the market situation and it is divided into three categories such as intermittent, continuous, and seasonal. In some cases such as Chemicals and Services and Paper products, Textiles etc., production would be generally continuous not withstanding some slight fluctuations in demand. In some others like woolen rugs, sugar etc., markets would be seasonal. In certain services, repairs and made-to-order goods, the demand as well as production could be continuous or halting and intermittent. If production is continuous and sales are continuous, there would be equitable distribution of overheads leading to overall efficiency and profitability, other things being the same. But in seasonal industries, high amount of working capital becomes necessary to purchase raw materials in bulk at a time for meeting the demand which could be uniform or vary from one month to another. Such seasonal nature of production results in carrying overheads even in lean months. If production is intermittent with busy season in some months, and no business at all in certain other months, assembling the resources to carry on production during peak periods would be difficult, particularly if competition is intense, while the problem of carrying overheads all through continues to exist. So much so, the nature of production, determined by the nature of market affects the performance of enterprises. Keeping this in view, an attempt is made to examine the nature of production of healthy and sick SSEs.

\section{METHODOLOGY}

The data needed for the present study are gathered from both primary and secondary sources. The sources of secondary data include publications of the Government of India and Development Commissionerate of Micro Small and Medium Enterprises (MSMEs), New Delhi; Reports on Currency and Finance published by the Reserve Bank of India and Centre for Monitoring the Indian Economy (CMIE); Annual Reports of Small Industries Development Bank of India (SIDBI); Annual Survey of Industries, Directorate of Economics and Statistics, Government of Andhra Pradesh; and Annual Reports of State level promotional /financial institutions such as Andhra Pradesh State Financial Corporation(AFSFC), Andhra Pradesh State Small Industries Development Corporation (APSSIDC), Andhra Pradesh Industrial Infrastructure Development Corporation (APIIDC) and periodical publications and office records of the Commissionerate of Industries, Government of Andhra Pradesh, Hyderabad. 
The primary data are gathered from well-structured schedules administered to sample SSEs. it is proposed to examine the performance of only those SSEs which are registered and which received financial assistance exceeding Rs.50 lakhs from the APSFC as on $31^{\text {st }}$ March, 2007. As there are 1,117 enterprises as on $31^{\text {st }}$ March, 2007, a sample of 200 SSEs (20 per cent) is taken comprising of 100 healthy and 100 sick enterprises on stratified sampling basis.

As the classification of the SSEs made by different agencies in the state is not uniform, purposively 10 major industrial categories are identified. Those industries are: (1) Food Products \& Processing; (2) Chemical Products; (3) Basic Metal Products; (4) Textiles; (5) Machinery (except Electrical Machinery); (6) Paper \& Paper products; (7) Electrical Machinery \& Appliances; (8) Miscellaneous Manufacturing Industries; (9) Services; and (10) Others. Others include Beverages, Tobacco products, printing \& Publishing, Leather, Petroleum Products etc., which are not included in the first nine categories. With a view to ensure that the 'Sample' is truly representative of the Universe which comprises of SSEs engaged in different lines of activity and situated in different regions of the State, stratified random sampling method is followed. As it is intended to study the performance SSEs in Andhra Pradesh, purposively it is decided to select 100 Healthy and 100 Sick enterprises. For analyzing financial performance of both healthy and sick enterprises, ratio analysis is used. For depiction of the data simple and comprehensive tables are used. To speed up processing of data with accuracy, computer facility is used..

\section{PERFORMANCE OF SSES IN PRODUCTION}

Industrial category-wise analysis of nature of production in both healthy and sick SSEs is presented in Table-1. It can be observed from the table that 75 per cent of healthy and 62 per cent of sick enterprises have continuous production, 10 per cent of healthy and nine per cent of sick have seasonal production, 15 per cent of healthy and 29 per cent of sick have intermittent production. Seasonal production is found only in Food Products \& Processing, Paper and Paper Products and in Others category.

Intermittent production is observed in all categories except in Food Products \& Processing and Electrical Machinery \& Appliances categories. Basic Metal Industry, Paper \& Paper products and Textiles have higher incidence of sickness among the enterprises with intermittent production, and like-wise high incidence of sickness is found in Food Products, Machinery, Electrical Machinery \& Appliances, though production is continuous. The data do not suggest any causal connection between continuity or seasonality of production and sickness of enterprises, as sickness is found in all categories of industries irrespective nature of production.

Unlike other enterprises SSEs also face various problems in production on account of shortage of critical raw materials, power cuts, deliberate slow down due to slow movement of finished products, transport bottlenecks both in securing raw materials and sale of finished products and so on. These factors lead to dullness in production, which could be the cause and consequence of dullness in sales. While occasional dullness in production or sale is a problem that visits any enterprise, continuous dullness in production or sales leads to low sales turn over and low level of profits or even losses. So duration of dullness in production or sale affects the health of enterprises and could be one of the indicators of their performance. Hence data relating to duration of dullness in both healthy and sick SSEs are gathered industrial category-wise and the same are presented in Table-2.

Table-1: Industrial category-wise analysis of nature of production in Healthy and Sick SSEs

\begin{tabular}{|c|c|c|c|c|c|c|c|}
\hline \multirow{2}{*}{ Industrial category } & \multirow{2}{*}{ Number } & \multicolumn{2}{|c|}{ Continuous } & \multicolumn{2}{|c|}{ Seasonal } & \multicolumn{2}{|c|}{ Intermittent } \\
\hline & & Healthy & Sick & Healthy & Sick & Healthy & Sick \\
\hline Food Products \& Processing & $\begin{array}{c}(100.00) \\
12 \\
(12.00) \\
\end{array}$ & $\begin{array}{c}(75.00) \\
9 \\
(12.00)\end{array}$ & $\begin{array}{c}(83.33) \\
10 \\
(16.13) \\
\end{array}$ & $\begin{array}{c}(25.00) \\
3 \\
(30.00)\end{array}$ & $\begin{array}{c}(16.67) \\
2 \\
(22.22)\end{array}$ & - & - \\
\hline Chemical Products & $\begin{array}{c}(100.00) \\
9 \\
(9.00) \\
\end{array}$ & $\begin{array}{c}(88.89) \\
8 \\
(10.67) \\
\end{array}$ & $\begin{array}{c}(77.78) \\
7 \\
(11.29) \\
\end{array}$ & - & - & $\begin{array}{c}(11.11) \\
1 \\
(6.67) \\
\end{array}$ & $\begin{array}{c}(22.22) \\
2 \\
(6.89) \\
\end{array}$ \\
\hline Basic Metals & $\begin{array}{c}(100.00) \\
2 \\
(2.00) \\
\end{array}$ & $\begin{array}{c}(50.00) \\
1 \\
(1.33)\end{array}$ & - & - & - & $\begin{array}{c}(50.00) \\
1 \\
(6.67)\end{array}$ & $\begin{array}{c}(100.00) \\
2 \\
(6.89) \\
\end{array}$ \\
\hline Textiles & $\begin{array}{c}(100.00) \\
3 \\
(3.00) \\
\end{array}$ & $\begin{array}{c}(100.00) \\
3 \\
(4.00) \\
\end{array}$ & $\begin{array}{c}(33.33) \\
1 \\
(1.61) \\
\end{array}$ & - & - & - & $\begin{array}{c}(66.67) \\
2 \\
(6.89) \\
\end{array}$ \\
\hline Machinery except Electrical Machinery & $\begin{array}{c}(100.00) \\
5 \\
(5.00)\end{array}$ & $\begin{array}{c}(80.00) \\
4 \\
(5.33)\end{array}$ & $\begin{array}{c}(80.00) \\
4 \\
(6.45)\end{array}$ & - & - & $\begin{array}{c}(20.00) \\
1 \\
(1.67)\end{array}$ & $\begin{array}{c}(20.00) \\
1 \\
(6.89)\end{array}$ \\
\hline Paper \& Paper Products & $\begin{array}{c}(100.00) \\
2 \\
(2.00)\end{array}$ & $\begin{array}{c}(50.00) \\
1 \\
(1.33) \\
\end{array}$ & - & $\begin{array}{c}(50.00) \\
1 \\
(10.00)\end{array}$ & - & - & $\begin{array}{c}(100.00) \\
2 \\
(6.89)\end{array}$ \\
\hline Electrical Machinery \& Appliances & $\begin{array}{c}(100.00) \\
2 \\
(2.00)\end{array}$ & $\begin{array}{c}(100.00) \\
2 \\
(2.67)\end{array}$ & $\begin{array}{c}(100.00) \\
2 \\
(3.22)\end{array}$ & - & - & - & - \\
\hline
\end{tabular}




\begin{tabular}{|c|c|c|c|c|c|c|c|}
\hline Miscellaneous manufacturing & $\begin{array}{c}(100.00) \\
4 \\
(4.00) \\
\end{array}$ & $\begin{array}{c}(75.00) \\
3 \\
(4.00) \\
\end{array}$ & $\begin{array}{c}(75.00) \\
3 \\
(4.84) \\
\end{array}$ & - & - & $\begin{array}{c}(25.00) \\
1 \\
(1.67) \\
\end{array}$ & $\begin{array}{c}(25.00) \\
1 \\
(3.45) \\
\end{array}$ \\
\hline Services & $\begin{array}{c}(100.00) \\
9 \\
(9.00) \\
\end{array}$ & $\begin{array}{c}(88.89) \\
8 \\
(10.67) \\
\end{array}$ & $\begin{array}{c}(77.78) \\
7 \\
(11.29) \\
\end{array}$ & - & - & $\begin{array}{c}(11.11) \\
1 \\
(1.67) \\
\end{array}$ & $\begin{array}{c}(22.22) \\
2 \\
(6.89) \\
\end{array}$ \\
\hline Others & $\begin{array}{c}(100.00) \\
52 \\
(52.00) \\
\end{array}$ & $\begin{array}{c}(69.23) \\
36 \\
(48.00) \\
\end{array}$ & $\begin{array}{c}(53.84) \\
28 \\
(45.17) \\
\end{array}$ & $\begin{array}{c}(11.54) \\
6 \\
(60.00) \\
\end{array}$ & $\begin{array}{c}(13.46) \\
7 \\
(77.78)\end{array}$ & $\begin{array}{c}(19.23) \\
10 \\
(66.65)\end{array}$ & $\begin{array}{c}(32.69) \\
17 \\
(58.61)\end{array}$ \\
\hline Total & $\begin{array}{c}(100.00) \\
100 \\
(100.00) \\
\end{array}$ & $\begin{array}{c}(75.00) \\
75 \\
(100.00) \\
\end{array}$ & $\begin{array}{c}(62.00) \\
62 \\
(100.00) \\
\end{array}$ & $\begin{array}{c}(10.00) \\
10 \\
(100.00) \\
\end{array}$ & $\begin{array}{c}(9.00) \\
9 \\
(100.00) \\
\end{array}$ & $\begin{array}{c}(15.00) \\
15 \\
(100.00) \\
\end{array}$ & $\begin{array}{c}(29.00) \\
29 \\
(100.00) \\
\end{array}$ \\
\hline
\end{tabular}

Figures in brackets above the absolute numbers indicate percentages to horizontal totals, while figures in brackets below the absolute numbers indicate percentages to vertical totals.

Table-2: Industrial Category-wise analysis of duration of dullness of business in Healthy and Sick SSEs.

\begin{tabular}{|c|c|c|c|c|c|c|c|c|c|}
\hline \multirow{2}{*}{ Industrial category } & \multirow{2}{*}{ Number } & \multicolumn{2}{|c|}{ 0-6months } & \multicolumn{2}{|c|}{ 6-12 months } & \multicolumn{2}{|c|}{ 12-24 months } & \multicolumn{2}{|c|}{ Above 24 months } \\
\hline & & Healthy & Sick & Healthy & Sick & Healthy & Sick & Healthy & Sick \\
\hline $\begin{array}{l}\text { Food Products \& } \\
\text { Processing }\end{array}$ & $\begin{array}{c}(100.00) \\
12 \\
(12.00)\end{array}$ & - & $\begin{array}{c}(16.67) \\
2 \\
(7.69)\end{array}$ & - & - & - & $\begin{array}{c}(33.33) \\
4 \\
(15.38)\end{array}$ & - & $\begin{array}{c}50.00) \\
6 \\
(24.00)\end{array}$ \\
\hline Chemical Products & $\begin{array}{c}(100.00) \\
9 \\
(9.00) \\
\end{array}$ & $\begin{array}{c}(88.89) \\
8 \\
(10.00) \\
\end{array}$ & $\begin{array}{c}(33.33) \\
3 \\
(11.54) \\
\end{array}$ & $\begin{array}{c}(11.11) \\
1 \\
(6.25) \\
\end{array}$ & $\begin{array}{c}(55.55) \\
5 \\
(21.74) \\
\end{array}$ & - & $\begin{array}{c}(11.11) \\
1 \\
(3.84) \\
\end{array}$ & - & - \\
\hline Basic Metals & $\begin{array}{c}(100.00) \\
2 \\
(2.00) \\
\end{array}$ & $(x+0)$ & (1) & (1) & 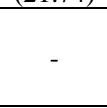 & - & $\begin{array}{c}(50.00) \\
1 \\
(3.84) \\
\end{array}$ & - & $\begin{array}{c}50.00) \\
1 \\
(4.00) \\
\end{array}$ \\
\hline Textiles & $\begin{array}{c}(100.00) \\
3 \\
(3.00) \\
\end{array}$ & $\begin{array}{c}(66.67) \\
2 \\
(2.50) \\
\end{array}$ & $\begin{array}{c}(33.33) \\
1 \\
(3.85) \\
\end{array}$ & $\begin{array}{c}(33.33) \\
1 \\
(6.25) \\
\end{array}$ & - & - & - & - & $\begin{array}{c}(66.67) \\
2 \\
(8.00) \\
\end{array}$ \\
\hline $\begin{array}{c}\text { Machinery except } \\
\text { Electrical Machinery }\end{array}$ & $\begin{array}{c}(100.00) \\
5 \\
(5.00) \\
\end{array}$ & $\begin{array}{c}(80.00) \\
4 \\
(5.00)\end{array}$ & (1) & $\begin{array}{c}(20.00) \\
1 \\
(6.25) \\
\end{array}$ & $\begin{array}{c}(60.00) \\
3 \\
(13.04) \\
\end{array}$ & - & $\begin{array}{c}(40.00) \\
2 \\
(7.68) \\
\end{array}$ & - & $(0.0)$ \\
\hline Paper \& Paper Products & $\begin{array}{c}(100.00) \\
2 \\
(2.00) \\
\end{array}$ & $\begin{array}{c}(100.00) \\
2 \\
(2.50)\end{array}$ & - & - & $\begin{array}{c}(50.00) \\
1 \\
(4.35) \\
\end{array}$ & - & $\begin{array}{c}(50.00) \\
1 \\
(3.84) \\
\end{array}$ & - & - \\
\hline $\begin{array}{l}\text { Electrical Machinery \& } \\
\text { Appliances }\end{array}$ & $\begin{array}{c}(100.00) \\
2 \\
(2.00) \\
\end{array}$ & $\begin{array}{c}(50.00) \\
1 \\
(1.25) \\
\end{array}$ & $\begin{array}{c}(50.00) \\
1 \\
(3.85) \\
\end{array}$ & $\begin{array}{c}(50.00) \\
1 \\
(6.25) \\
\end{array}$ & $\begin{array}{c}(50.00) \\
1 \\
(4.35)\end{array}$ & - & - & - & - \\
\hline $\begin{array}{l}\text { Miscellaneous } \\
\text { manufacturing }\end{array}$ & $\begin{array}{c}(100.00) \\
4 \\
(4.00) \\
\end{array}$ & $\begin{array}{c}(75.00) \\
3 \\
(3.75)\end{array}$ & - & $\begin{array}{c}(25.00) \\
1 \\
(6.25)\end{array}$ & $\begin{array}{c}(25.00) \\
1 \\
(4.35)\end{array}$ & - & $\begin{array}{c}(75.00) \\
3 \\
(11.53) \\
\end{array}$ & - & - \\
\hline Services & $\begin{array}{c}(100.00) \\
9 \\
(9.00) \\
\end{array}$ & $\begin{array}{c}(88.89) \\
8 \\
(10.00) \\
\end{array}$ & $\begin{array}{c}(77.78) \\
7 \\
(26.92) \\
\end{array}$ & $\begin{array}{c}(11.11) \\
1 \\
(6.25) \\
\end{array}$ & $\begin{array}{c}(22.22) \\
2 \\
(8.70)\end{array}$ & - & - & - & - \\
\hline Others & $\begin{array}{c}(100.00) \\
52 \\
(52.00) \\
\end{array}$ & $\begin{array}{c}(80.77) \\
42 \\
(52.50)\end{array}$ & $\begin{array}{c}(23.07) \\
12 \\
(46.15) \\
\end{array}$ & $\begin{array}{c}(19.23) \\
10 \\
(62.50)\end{array}$ & $\begin{array}{c}(19.23) \\
10 \\
(43.47)\end{array}$ & - & $\begin{array}{c}(26.92) \\
14 \\
(53.85) \\
\end{array}$ & - & $\begin{array}{c}(30.78) \\
(16 \\
(64.00)\end{array}$ \\
\hline Total & $\begin{array}{c}(100.00) \\
100 \\
(100.00) \\
\end{array}$ & $\begin{array}{c}(80.00) \\
80 \\
(100.00) \\
\end{array}$ & $\begin{array}{c}(26.00) \\
26 \\
(100.00) \\
\end{array}$ & $\begin{array}{c}(16.00) \\
16 \\
(100.00) \\
\end{array}$ & $\begin{array}{c}(23.00) \\
23 \\
(100.00) \\
\end{array}$ & - & $\begin{array}{c}(26.00) \\
26 \\
(100.00) \\
\end{array}$ & - & $\begin{array}{c}(25.00) \\
25 \\
(100.00) \\
\end{array}$ \\
\hline
\end{tabular}

Figures in brackets above the absolute figures indicate percentages to horizontal totals, while those below the absolute

numbers indicate percentages to vertical totals.

It can be observed from the table that 80 per cent of healthy and 26 per cent of sick SSEs have had dullness for 0-6 months; 16 per cent of healthy and 23 per cent of sick SSEs experienced dullness in business ranging from 6-12 months; 26 per cent of sick SSEs faced dullness for a period of 12-24 months and another 25 per cent experienced dullness for a period exceeding 24 months. It may be noted from the table that even healthy SSEs in almost all categories except Food Products \& Processing and Basic Metals faced dullness for a short spell not exceeding six months during the period under reference. But such short spells of dullness have not affected their health or pushed them to sickness. However, in some industrial categories such as Basic Metals, Papers \& Paper Products, Miscellaneous Manufacturing and Others Categories dullness extended from 12-24 months making them sick and like-wise Textiles and Food Products faced dullness for a period above 24 months. It is thus observed that dullness for longer periods spelt disaster to SSEs and pushed them into sickness.

Interaction with the entrepreneurs of both healthy and sick SSEs gave an insight into the reasons for varying spells of dullness experienced by different industrial categories and the data so obtained are captured in Table-3.

It may be observed from the table that 56 per cent of healthy and 64 per cent of sick SSEs cited competition from rivals as the reason for dullness. 14 per cent of healthy and 16 per cent of sick attribute dullness to technological changes, 26 per cent of healthy and 17 per cent of sick trace dullness to sudden changes in market conditions while two per cent of healthy concede incorrect estimation of product demand to be the reason for dullness.

Published By:

Blue Eyes Intelligence Engineering \& Sciences Publication

(C) Copyright: All rights reserved. 
Table 3: Industrial Category-wise analysis of reasons for dullness in business in Healthy and Sick SSEs.

\begin{tabular}{|c|c|c|c|c|c|c|c|c|c|c|c|}
\hline \multirow{3}{*}{$\begin{array}{l}\text { Industrial } \\
\text { category }\end{array}$} & \multirow{3}{*}{ Number } & \multicolumn{10}{|c|}{ Reasons for dullness as perceived by the Entrepreneurs } \\
\hline & & \multicolumn{2}{|c|}{$\begin{array}{c}\text { Competition from } \\
\text { Rivals }\end{array}$} & \multicolumn{2}{|c|}{ Technological Changes } & \multicolumn{2}{|c|}{$\begin{array}{c}\text { Changes in Market } \\
\text { conditions }\end{array}$} & \multicolumn{2}{|c|}{$\begin{array}{l}\text { Incorrect estimation } \\
\text { of product demand }\end{array}$} & \multicolumn{2}{|c|}{ Others } \\
\hline & & Healthy & Sick & Healthy & Sick & Healthy & Sick & Healthy & Sick & Healthy & Sick \\
\hline $\begin{array}{l}\text { Food Products \& } \\
\text { Processing }\end{array}$ & $\begin{array}{c}(100.00) \\
12 \\
(12.00)\end{array}$ & $\begin{array}{c}(75.00) \\
9 \\
(16.07) \\
\end{array}$ & $\begin{array}{c}(50.00) \\
6 \\
(4.37) \\
\end{array}$ & - & - & $\begin{array}{c}(25.00) \\
3 \\
(11.54)\end{array}$ & $\begin{array}{c}(33.33) \\
4 \\
(23.53)\end{array}$ & - & - & - & $\begin{array}{c}(16.67) \\
2 \\
(100.00)\end{array}$ \\
\hline Chemical Products & $\begin{array}{c}(100.00) \\
9 \\
(9.00)\end{array}$ & $\begin{array}{c}(88.89) \\
8 \\
(14.28)\end{array}$ & $\begin{array}{c}(66.67) \\
6 \\
(9.37)\end{array}$ & - & - & $\begin{array}{c}(11.11) \\
1 \\
(3.84)\end{array}$ & $\begin{array}{c}(33.33) \\
3 \\
(17.64)\end{array}$ & - & - & - & - \\
\hline Basic Metals & $\begin{array}{c}(100.00) \\
2 \\
(2.00)\end{array}$ & $\begin{array}{c}(50.00) \\
1 \\
(1.78)\end{array}$ & $\begin{array}{c}(50.00) \\
1 \\
(1.56)\end{array}$ & $\begin{array}{c}(50.00) \\
1 \\
(7.14)\end{array}$ & - & $\begin{array}{c}(50.00) \\
1 \\
(3.84)\end{array}$ & - & - & - & - & - \\
\hline Textiles & $\begin{array}{c}(100.00) \\
3 \\
(3.00)\end{array}$ & $\begin{array}{c}(33.33) \\
1 \\
(1.78)\end{array}$ & $\begin{array}{c}(66.67) \\
2 \\
(3.12)\end{array}$ & $\begin{array}{c}(66.67) \\
2 \\
(14.28)\end{array}$ & - & - & $\begin{array}{c}(33.33) \\
1 \\
(5.88)\end{array}$ & - & - & - & - \\
\hline $\begin{array}{c}\text { Machinery except } \\
\text { Electrical } \\
\text { Machinery }\end{array}$ & $\begin{array}{c}(100.00) \\
5 \\
(5.00)\end{array}$ & - & $\begin{array}{c}(60.00) \\
3 \\
(4.69)\end{array}$ & $\begin{array}{c}(20.00) \\
1 \\
(7.14)\end{array}$ & - & $\begin{array}{c}(40.00) \\
2 \\
(7.69)\end{array}$ & $\begin{array}{c}(40.00) \\
2 \\
(11.76)\end{array}$ & - & - & $\begin{array}{c}(40.00) \\
2 \\
(100.00)\end{array}$ & - \\
\hline $\begin{array}{l}\text { Paper \& Paper } \\
\text { Products }\end{array}$ & $\begin{array}{c}(100.00) \\
2 \\
(2.00)\end{array}$ & $\begin{array}{c}(50.00) \\
1 \\
(1.78)\end{array}$ & $\begin{array}{c}(50.00) \\
1 \\
(1.56)\end{array}$ & - & - & $\begin{array}{c}(50.00) \\
1 \\
(3.84)\end{array}$ & $\begin{array}{c}(50.00) \\
1 \\
(5.88)\end{array}$ & - & - & - & - \\
\hline $\begin{array}{c}\text { Electrical } \\
\text { Machinery \& } \\
\text { Appliances }\end{array}$ & $\begin{array}{c}(100.00) \\
2 \\
(2.00) \\
\end{array}$ & - & - & $\begin{array}{c}(100.00) \\
2 \\
(14.28) \\
\end{array}$ & $\begin{array}{c}(100.00) \\
2 \\
(12.50) \\
\end{array}$ & - & - & - & - & - & - \\
\hline $\begin{array}{l}\text { Miscellaneous } \\
\text { manufacturing }\end{array}$ & $\begin{array}{c}(100.00) \\
4 \\
(4.00)\end{array}$ & - & - & $\begin{array}{c}(25.00) \\
1 \\
(7.14)\end{array}$ & $\begin{array}{c}(50.00) \\
2 \\
(12.50)\end{array}$ & $\begin{array}{c}(75.00) \\
3 \\
(11.54)\end{array}$ & $\begin{array}{c}(50.00) \\
2 \\
(11.76)\end{array}$ & - & - & - & - \\
\hline Services & $\begin{array}{c}(100.00) \\
9 \\
(9.00)\end{array}$ & $\begin{array}{c}(89.89) \\
8 \\
(14.28) \\
\end{array}$ & $\begin{array}{c}(66.67) \\
6 \\
(9.37)\end{array}$ & - & - & $\begin{array}{c}(11.11) \\
1 \\
(11.54)\end{array}$ & $\begin{array}{c}(33.33) \\
3 \\
(17.64)\end{array}$ & - & - & - & - \\
\hline Others & $\begin{array}{c}(100.00) \\
52 \\
(52.00)\end{array}$ & $\begin{array}{c}(53.84) \\
28 \\
(50.00)\end{array}$ & $\begin{array}{c}(75.00) \\
39 \\
(60.94)\end{array}$ & $\begin{array}{c}(15.38) \\
8 \\
(57.14)\end{array}$ & $\begin{array}{c}(23.07) \\
12 \\
(75.00)\end{array}$ & $\begin{array}{c}(26.92) \\
14 \\
(53.85)\end{array}$ & $\begin{array}{c}(1.92) \\
1 \\
(5.88)\end{array}$ & $\begin{array}{c}(3.85) \\
2 \\
(100.00)\end{array}$ & - & - & - \\
\hline Total & $\begin{array}{c}(100.00) \\
100 \\
(100.00)\end{array}$ & $\begin{array}{c}(56.00) \\
56 \\
(100.00)\end{array}$ & $\begin{array}{c}(64.00) \\
64 \\
(100.00)\end{array}$ & $\begin{array}{c}(14.00) \\
14 \\
(100.00)\end{array}$ & $\begin{array}{c}(16.00) \\
16 \\
(100.00)\end{array}$ & $\begin{array}{c}(26.00) \\
26 \\
(100.00)\end{array}$ & $\begin{array}{c}(17.00) \\
17 \\
(100.00)\end{array}$ & $\begin{array}{c}(2.00) \\
2 \\
(100.00\end{array}$ & - & $\begin{array}{c}(2.00) \\
2 \\
(100.00)\end{array}$ & $\begin{array}{c}(2.00) \\
2 \\
(100.00)\end{array}$ \\
\hline
\end{tabular}

Figures in brackets above the absolute figures indicate percentages to horizontal totals, while those below the absolute numbers indicate percentages to vertical totals.

It could be observed from the table that competition from rivals in the matter of procurement of raw materials and sale of finished products, sudden changes in market conditions, technological changes including advancements, and to a limited extent incorrect initial projection of demand are the factors behind dullness in business. Though SSEs of all industrial categories by and large cited the same reasons for dullness in business, the impact of duration of dullness is found to be greater on some enterprises which eventually made them sick. While competition from rivals led to sickness in the case of Textiles, Machinery, Services and 'Others', technological changes had upset the fortunes of SSEs in Electrical Machinery \& Appliances and Miscellaneous Manufacturing categories. Similarly, Changes in market conditions badly affected Miscellaneous Manufacturing and Paper \& Paper Products categories. Thus while factors are same, their impact was different on different industrial categories. But dynamism, shrewdness and adaptability of entrepreneurs could prevent some enterprises from slipping into sickness. The remedy for this kind of problems lies in careful appraisal of business idea, in-built flexibility in production, even spatial distribution of industries through adoption of suitable strategies by the term lending and other promotional corporations.

\section{CONCLUSION}

Analysis of nature of production in healthy and sick SSEs in Andhra Pradesh reveals that 75 per cent of healthy and 62 per cent of sick enterprises have continuous production, 10 per cent of healthy and nine per cent of sick have seasonal production, 15 per cent of healthy and 29 per cent of sick have intermittent production. Seasonal production is found in Food Products \& Processing, Paper \& Paper Products and in other category. Production is intermittent in all categories except in Food Products \& Processing and Electrical Machinery \& Appliances categories. The data do not suggest or indicate any causal connection between periodicity of production and sickness, since sickness is found in SSEs belonging to all Industrial Categories irrespective of nature of production.

\section{AUTHORS PROFILE}

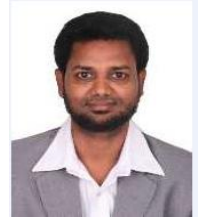

Dr. Pulidindi Venugopal, Professor Department of Technology Management School of Mechanical Engineering Vellore Institute of Technology Vellore-632014.pulidindi.venu@vit.ac.in

Dr. Pulidindi Venugopal is an enthusiastic marketing professor and a researcher. He started his teaching 
profession at VIT in 2009. He published 63 research articles in top rated journals, Case studies in top rated case centers and 'holds more than 15 Book chapters till 2019. He also produced 7 doctorates till date and holds two funded research projects given by Indian Council of Social Science and Research (ICSSR).

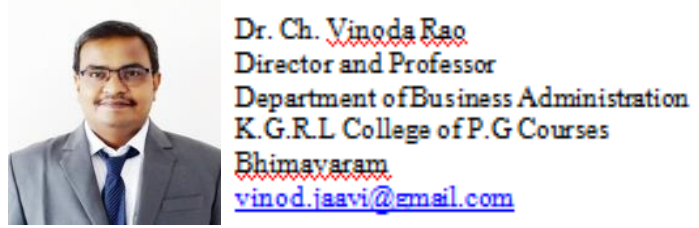

Dr. Ch. Vinoda Rao is a Professor and Head of the Department has Teaching Experience of 21 years and specialized in the area of Finance. He obtained his masters degree in Business Administration from Andhra University in the year of 1998 . He has qualified State Level Eligibility Test (SLET) conducted by APPSC Hyderabad in the year of 1999. In his academic excellence has published 5 national and one international journal with ISSN and wrote one book with ISBN and also participated and presented 16 National seminars and conferences. He has guided more than 375 MBA projects.

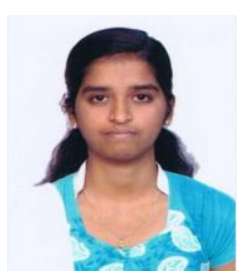

chapters till 2019.

S. Aswini Priya, Research Associate VIT Business School Vellore Institute of Technology Vellore-632014.priyapri.254@gmail.com

S. Aswini Priya is a Research Associate in VIT Business School, VIT. She pursued Integrated MBA in VIT Business School and started to pursue her doctorate in 2015. She worked as Project Associate in ICSSR funded project for two years and published 10 research papers in top reputed journals and 3 book 